\title{
Migrant sex workers left behind during COVID-19 pandemic
}

\author{
Elene $\operatorname{Lam}^{1,2}$ (1)
}

Received: 11 June 2020 / Accepted: 23 June 2020 / Published online: 16 July 2020

(C) The Canadian Public Health Association 2020

Dear Editor,

Jozaghi and Bird (2020) sent an important letter to the editor expressing their concerns about the vulnerability and risk of COVID-19 infection for sex workers. Migrant sex workers additionally face multiple layers of exclusion, including sexism, racism, xenophobia, language barriers, and precarious immigration status. These factors culminate to make them highly vulnerable during this time of the COVID-19 pandemic.

Migrants who are undocumented or have precarious immigration status are not eligible to apply for income support because they do not have a Social Insurance Number (Abji et al. 2020; Langille 2020). Additionally, they are fearful that their information will be shared with the Canadian Border Services Agency, because the Immigration and Refugee Protection Act prohibits work in sex work-related industries (Lam and Fudge 2020). Many migrant sex workers are still excluded from government income support and over $40 \%$ cannot access any emergency income supports at all (Lam 2020). The $\$ 350$ million "Emergency Community Support Fund" for community organizations serving vulnerable Canadians unfortunately also falls short. Most sex workerand migrant-organized grassroots organizations do not meet the criteria set out by the government, because they are not charitable or non-profit organizations (Amnesty International 2020).

Migrant sex workers have become more vulnerable and more marginalized in the past months and have an increased risk of exposure to COVID-19 because they may not be able to stay at home, physically distance, or stop work altogether. Migrant workers are excluded from the public health response

Elene Lam

elenelam2020@gmail.com

1 School of Social Work, McMaster University, Hamilton, ON, Canada

2 Butterfly (Asian and Migrant Sex Workers Support Network), 720 Spadina Ave, \#223, Toronto, ON M5S 2T9, Canada and from accessing basic health care (Abji et al. 2020; Migrant Rights Network 2020). Even though gender-based violence and anti-Asian racism have become heightened during the pandemic, many migrant sex workers cannot contact service providers out of fear (Lam et al. 2020; Satini and Lam 2020).

Most strikingly, instead of receiving various types of support, migrant sex workers are instead continuing to be targeted by law enforcement officers. Many provincial and municipal governments have passed an emergency order to increase the power of law enforcement - for example, the Ontario government has imposed an ID requirement and allowed the police to arrest without a warrant if they reasonably suspect that somebody has violated provincial order (Lam et al. Scott, 2020). It has also allowed the police to access the personal information of those who have tested positive for COVID-19 (Rocca 2020), which is not only an invasion of privacy but also creates barriers for undocumented and criminalized community members from accessing testing and treatment.

COVID-19 has blatantly exposed the cracks in the social system. Three months into the pandemic response, migrant sex workers should not be left behind. Canada must take immediate action to protect the rights of migrants and sex workers by ensuring equal access to income support and health services, and an end to repressive law enforcement policies. The only way out of the pandemic is if we work together to ensure the health and well-being of all communities in Canada. Migrant sex workers cannot be left behind.

\section{References}

Abji, S., Pintin-Perez, M., \& Bhuyan, R. (2020). In Canada, non-status women are being left behind: Non-status women remain largely invisible in the COVID-19 public health response and emergency support programs. Open Democracy. Retrieved from: https://www. opendemocracy.net/en/pandemic-border/canada-non-statuswomen-are-being-left-behind/. Accessed 10 June 2020.

Amnesty International. (2020). Open Letter: Canada must protect the rights of migrant and sex workers during COVID-19 by ensuring access to emergency income supports. Retrieved from https://www. amnesty.ca/news/canada-must-protect-rights-sex-workers-during- 
covid-19-ensuring-access-emergency-income. Accessed 10 June 2020.

Jozaghi, E., \& Bird, L. (2020). COVID-19 and sex workers: human rights, the struggle for safety and minimum income. Canadian Journal of Public Health. https://doi.org/10.17269/s41997-02000350-1.

Lam, E. (2020). How the Asian migrant workers in massage parlours and sex industry are affected by COVID-19? (Butterfly). Retrieved from: https://www.butterflysw.org/publication. Accessed 10 June 2020.

Lam, E., Deck, A. M., \& Chu, S. (2020). Ontario's anti-trafficking initiative. The lawyer's daily. https://www.thelawyersdaily.ca/articles/ 18322/ontario-s-anti-human-trafficking-initiative-elene-lamannemargaret-deck-sandra-ka-hon-chu?spotlight $=1$.

Lam, E., \& Fudge, J. (2020) Migrant sex workers and the pandemic: magnifying inequality and discrimination. Canadian Law of Work Forum. Retrieved from: http://lawofwork.ca/migrant-sex-workers/. Accessed 10 June 2020.

Lam, E., Wong, V., \& Scott, M. (2020). Covid-19, policing, and the exacerbation of pre-existing inequalities. Globalization Working Papers: Covid-19 Urgent Responses. 20(1):13-16.
Langille, A. (2020). How the Canada Emergency Response Benefit is failing low-income precarious workers, and how it can be fixed? Canadian Law of Work Forum. Retrieved from: http:/lawofwork. ca/how-the-canada-emergency-response-benefit-is-failing-lowincome-precarious-workers-and-how-it-can-be-fixed/. Accessed 10 June 2020.

Migrant Rights Network (2020). COVID-19 Response and recovery must ensure migrant rights. Retrieved from: https://migrantrights.ca/ covid19/. Accessed 10 June 2020.

Rocca, R. (2020). Coronavirus: Civil liberties group concerned as Ontario cops get IDs of those who test positive. Global News. Retrieved from https://globalnews.ca/news/6865929/coronavirus-civilliberties-ontario-cops/. Accessed 10 June 2020.

Satini, T. \& Lam, E. (2020). A pathway to end violence against migrant sex workers: access, safety, dignity and justice. Retrieved from https://www.butterflysw.org/legal-information-for-services-prov. Accessed 10 June 2020.

Publisher's note Springer Nature remains neutral with regard to jurisdictional claims in published maps and institutional affiliations. 